\title{
LITERASI DIGITAL DALAM PEMBENTUKAN SELF-ESTEEM DENGAN BERWAWASAN KEBANGSAAN NASIONAL DI SEKOLAH TEMAN BELAJAR CIPINANG JAKARTA TIMUR
}

\author{
Dianingtyas M. Putri ${ }^{1}{ }^{*}$, Sharon Azhari ${ }^{1}$, Berkah I. Santoso ${ }^{2}$, Azura Puti ${ }^{1}$, Tuti Widiastuti ${ }^{1}$ \\ ${ }^{1}$ Program Studi Ilmu Komunikasi, Fakultas Ekonomi dan Ilmu Sosial, \\ ${ }^{2}$ Program Studi Teknik Informatika, Fakultas Teknik dan Ilmu Komputer, Universitas Bakrie, Indonesia \\ E-mail: dianingtyas.putri@bakrie.ac.id*, sharon.auliazhr@gmail.com, berkah.santoso@bakrie.ac.id, \\ azuraputi2@gmail.com, tuti.widiastuti@bakrie.ac.id \\ Received: July 15, 2021 | Revised: September 17, 2021 | Accepted: September 22, 2021 \\ DOI: https://doi.org/10.36782/ijsr.v3i2.88
}

\begin{abstract}
ABSTRAK
Kemajuan teknologi digital saat pandemi Covid-19 memiliki peran penting dalam komunikasi dan informasi. Namun, terbatasnya ruang gerak karena PPKM yang diperpanjang memberikan peluang dalam mengakses media sosial dalam waktu yang tidak singkat. Intensitas penggunaan media sosial yang terlalu lama dapat memengaruhi kesehatan mental diri bukan saja pada remaja, tetapi juga anak-anak usia dini. Kegiatan Pengabdian kepada Masyarakat (PkM) ini dilakukan di Sekolah Teman Belajar, Cipinang Jakarta Timur yang masih minim pengetahuan penggunaan media sosial serta kurang kesadaran dari para orang tua melakukan pendampingan pada anak-anak mereka. Tujuan kegiatan pengabdian dilakukan ialah untuk memberikan pemahaman melalui metode literasi digital dalam pembentukan self-esteem dengan wawasan kebangsaan nasional. Metode pelaksanaan yang dilakukan berupa melakukan pendampingan dan pelatihan peserta didik dengan melibatkan orang tua peserta didik. Kemudian, memberikan pemahaman terkait parenting digital, dimana sebagai orang tua juga harus mengikuti perkembangan konten yang dikemas melalui media sosial. Selain itu, peserta didik yang masih usia dini diperkenalkan pada tokoh pewayangan yaitu Arjuna dan Srikandi yang dikemas melalui video animasi. Hasil kegiatan menunjukkan peserta memahami penjelasan yang diberikan oleh fasilitator. Kemudian dengan pendekatan interactive experience sharing yang mengimplementasikan $5 \mathrm{~W}+1 \mathrm{H}$ terjadi keterbukaan diri pada peserta didik, dalam hal ini mau membuat ide cerita yang nantinya dari hasil ide cerita tersebut digambarkan pada video animasi Arjuna dan Srikandi sebagai ikon Sobatmainku. Proses pembuatan ide cerita merupakan proses pembentukan self-esteem, selanjutnya peserta dibekali mengajak keluarga untuk membuat konten-konten yang menghibur dengan mengangkat nilai-nilai budaya sebagai temanya baik di TikTok maupun Instagram, hal ini bertujuan sebagai upaya membentuk identitas bangsa.
\end{abstract}

Kata kunci: Budaya, Literasi Digital, Media Sosial, Self-Esteem, Wawasan Kebangsaan.

\section{ABSTRACT}

Advances in digital technology during the Covid-19 pandemic turned out to have an important role in communication and information. However, the limited space for movement due to the extended PPKM provides opportunities to access social media in a short time. The intensity of 
using social media for too long can affect the mental health of themselves not only in adolescents, it can also affect children at an early age. This Community Service Activity (PKM) was carried out at the Sekolah Teman Belajar, Cipinang East Jakarta, where there was still a lack of knowledge about the use of social media and lack of awareness of parents in assisting their children. The purpose of the service activities carried out is to provide understanding through digital literacy methods in the formation of self-esteem with national insight. The implementation method is carried out in the form of providing assistance and training to students by involving the parents of students. Then, provide an understanding of digital parenting, where as parents must also follow the development of content packaged through social media. In addition, students who are still at an early age are introduced to wayang characters, namely Arjuna and Srikandi which are packaged through animated videos. The results of the activity showed that the participants understood the explanation given by the facilitator. Then with an interactive experience sharing approach that implements $5 \mathrm{~W}+1 \mathrm{H}$ there is self-disclosure to students, in this case they want to make story ideas which later on from the results of the story ideas are depicted in the animated video of Arjuna and Srikandi as icons of my friends. The process of making story ideas is a process of forming self-esteem, then participants are equipped to invite families to create entertaining content by raising cultural values as the theme on both TikTok and Instagram, this aims as an effort to form national identity.

Keywords: Culture, Digital Literacy, Social Media, Self-Esteem, National Insight.

\section{PENDAHULUAN}

Mengetahui kondisi Indonesia yang belum sepenuhnya pulih dari dampak Pandemi Covid19 hingga kini ternyata mengena ke beragam aspek dan lini. Selain itu, baru-baru ini juga dikabarkan terdapat varian baru yang masuk ke Indonesia. Hal ini diperkuat oleh Juru bicara (Jubir) vaksinasi Covid-19 dr. Siti Nadia Tarmizi pada konferensi pers secara virtual yang menyatakan bahwa Kementerian Kesehatan (Kemenkes) telah mendeteksi terdapat 10 kasus varian baru B 117. la mengingatkan sebagai antisipasi utama agar tidak terjadi lonjakan kasus seperti di negara India, maka perlu adanya pembatasan mobilitas serta tetap melakukan protokol kesehatan.
Situasi ini menjadi suatu tantangan yang tidak mudah, Putri dan Listriani (2021), menyampaikan dengan tuntutan meningkatkan kualitas Sumber Daya Manusia (SDM) akibat dari pandemi ini memberikan dampak baik pihak sekolah atau kampus yakni pendidik harus mencari upaya dengan kondisi yang terbatas tersebut agar proses belajar mengajar kelas daring tetap berjalan dengan baik, agar kualitas peserta didik tidak tertinggal. Faktanya, rencana sekolah tatap muka yang akan dibuka di tahun 2021 masih belum memungkinkan untuk dilangsungkan. Hal tersebut memengaruhi psikis baik peserta didik dengan pendidik, serta significant others peserta didiknya. Pemberian materi dilakukan melalui medium Zoom, Google Meet, Webex, kurang berjalan secara optimal 
(Putri \& Listriani, 2021). Dengan kata lain, kurang optimalnya proses belajar mengajar melalui daring serta pembelajaran jarak jauh (PJJ) ini. Era Revolusi Industri 4.0 atau yang dikenal dengan era 4.0 ini selain dapat menjawab permasalahan terhadap tantangan sosial ekonomi dalam masyarakat, juga menjadi solusi saat kondisi pandemi dimana membuat semua elemen bergantung pada solusi teknologi digital.

Dengan intensitas penggunaan dan pemanfaatan media internet tersebut terdapat efek yang ditimbulkan yakni kurangnya pendampingan oleh keluarga saat penggunaan media internet, peserta didik yang masih usia dini menggunakan bukan hanya PJJ akan tetapi mereka juga mengakses media sosial seperti Instagram, TikTok, YouTube dan sebagainya dalam kurun waktu yang lama. Hal ini disebabkan salah satu faktornya adalah ketika proses kelas daring atau PJJ tersebut orang tua bekerja, dan terbagi fokusnya antara pekerjaan serta pendampingan anak-anak mereka saat kelas daring atau PJJ berlangsung. Menjadi suatu yang dilematis bagi semua pihak, oleh karenanya literasi media dan digital masih harus digaungkan baik berupa kampanye sosial maupun beragam kegiatan yang bertujuan untuk mengajak serta memberikan pemahaman betapa pentingnya peran significant other juga turut bertanggung jawab dalam membentuk SDM yang berkualitas.
Mengapa kegiatan yang terkait dengan literasi media dan digital ini sangat penting? Limilia dan Aristi (2019), menyatakan bahwa pemahaman antara literasi media dan literasi digital berbeda. Sebelumnya, dikenal sebagai literasi media saja yang mana mengadvokasi pentingnya sikap kritis terhadap televisi, selain itu adanya era kelahiran komputer konsep literasi media mulai dipahami menjadi keterampilan yang dimiliki oleh individu untuk dapat mengoperasikannya. Selanjutnya, konsep berkembang dan bertransformasi menjadi literasi informasi saat media internet semakin berkembang sehingga banyak juga munculnya hoaks, maka literasi digital merupakan jawabannya, literasi digital ialah keterampilan dalam menggunakan media secara efektif sehingga individu dapat mengetahui sumber referensi yang relevan dan valid (Limilia \& Aristi, 2019).

Dalam materi pendukung literasi digital menurut Paul Gilster dalam Aziz dkk. (2020), diartikan sebagai kemampuan untuk memahami dan menggunakan informasi dalam berbagai bentuk dari berbagai sumber yang sangat luas yang diakses melalui piranti komputer. Sementara itu Belshaw (2011), menyebutkan terdapat delapan elemen esensial untuk mengembangkan literasi digital yakni kultural, kognitif, konstruktif, komunikatif, kepercayaan diri, kreatif, kritis dalam menyikapi konten, dan bertanggung jawab secara sosial. 
Samovar dkk. (2013) menjelaskan "culture is communication and communication is culture" (budaya adalah komunikasi dan komunikasi adalah budaya). Kita belajar budaya via komunikasi, pada saat yang bersamaan komunikasi merupakan refleksi dari budaya kita. Budaya sendiri terbentuk atas values, beliefs, attitude, dan behavior. Samovar dkk. (2013) menjelaskan bahwa bagaimana setiap individu memiliki sudut pandang yang berbeda karena salah satu faktornya adalah budaya yang membentuk perpektif tersebut.

Merujuk yang disampaikan oleh Belshaw (2011), aspek kognitif memiliki pengaruh dalam menilai suatu konten, maka inilah yang dinamakan persepsi. Persepsi ialah bagaimana kita memahami dunia fisik dan sosial, lalu bagaimana kita membangun suatu realitas. Persepsi memberi makna pada kekuatan eksternal dengan memungkinkan diri kita untuk menafsirkan, mengkategorikan, dan mengatur rangsangan yang dipilih untuk dipantau (Samovar dkk., 2013).

Telah disebutkan intensitas penggunaan media internet dalam kurun waktu yang lama dapat mengakibatkan kondisi fisiologis dapat terganggu. Pola konsumsi media di kalangan anak dan remaja saat ini telah mengkhawatirkan. Beberapa penelitian terkait konsumsi media menunjukkan fenomena kecanduan internet atau adiksi internet banyak menimbulkan dampak negatif jika dibandingkan dengan positifnya. Faktanya, dengan kurangnya pendampingan anak-anak maupun remaja menyebabkan mereka berselancar beragam konten tanpa memahami arti atau makna dibalik konten yang disajikan tersebut. Ini bukanlah semata tugas dan tanggung jawab dari pihak pemerintah yang membuat aturan akan tetapi orang tua dalam hal ini keluarga yang merupakan satuan inti dalam proses pembentukan diri juga turut memiliki andil.

\section{RUMUSAN MASALAH}

Siapakah iGeneration? Para ahli menyatakan bahwa gen Z memiliki karakteristik yang sangat berbeda dengan generasi-generasi sebelumnya. Jenkis (2018), menyampaikan gen Z memiliki harapan, preferensi, serta perspektif kerja yang berbeda (Tulgan \& Rainmaker, 2013). Generasi ini memilih membangun komunikasinya melalui medium, akibatnya terjadi kesenjangan keterampilan terjadi. Selain itu, penggunaan media sosial yang intens ternyata tidak selalu memberikan keuntungan karena gen Z rentan stress. Generasi ini dalam mengelola tingkat stress masih minim, sehingga memungkinkan gen $Z$ mudah labil akibat terpaan informasi dan kondisi yang cepat berubah dan secara acak (Tulgan \& Rainmaker, 2013).

Dengan kata lain, mereka mengalami kesulitan dalam mengelola emosi diri dan pikirannya ketika diterpa informasi melalui media sosial secara beruntun. Intensitas penggunaan media sosial tersebut dapat 
mengganggu kesehatan mental yakni komunikasi masih minim, sehingga tak jarang meningkatnya kecemasan diri (self-anxiety), sering menimbulkan salah persepsi dalam sehingga akan memengaruhi penghargaan mengartikan pesan.

terhadap diri sendiri (self-esteem) (Rakhmat, 2018).

Banyak konten-konten yang disajikan bersifat radikal, dan sebagainya, pernyataan ini juga disampaikan oleh Juru Bicara (Jubir) Kementerian Kominfo, Dedy Permadi, yang menyatakan hingga kini terdapat 3.640 konten yang telah di takedown mengenai ujaran Suku, Agama, Ras, dan Antargolongan (SARA). Selain itu, konten-konten yang disajikan pun juga kurang mengangkat wawasan kebangsaan nasional Indonesia, yang mana data dari Badan Pusat Statistik (BPS) tahun 2017 mengungkapkan bahwa sebanyak 60,80\% dari masyarakat mengatakan setuju, kurangnya kecintaan terhadap Negara Kesatuan Republik Indonesia sebagai salah satu faktor penyebab timbulnya berbagai permasalahan bangsa (Badan Pusat Statistik, 2017).

Generasi yang tumbuh dengan akses yang tak terbatas dalam teknologi digital akan memengaruhi aspek kognitifnya dimana generasi tersebut memiliki cara berpikir yang berbeda hingga perilakunya. Selanjutnya, pola interaksi Generasi Z atau iGeneration yang cenderung menyukai interaksi komunikasi melalui media sosial dibandingkan harus komunikasi tatap muka. Efeknya ialah, kemampuan mereka dalam memahami simbolsimbol baik secara verbal dan nonverbal

\section{TINJAUAN KEBIJAKAN DAN LITERATUR}

\section{Self-Esteem (Harga Diri)}

Secara sederhana self-esteem didefinisikan dengan bagaimana seseorang menghargai dirinya terhadap kemampuan yang dimilikinya. Vohs dan Baumeister dalam jurnalnya juga mendefinisikan self-esteem merujuk pada apa yang seorang rasakan tentang diri mereka terkait dengan pentingnya hubungan interpersonal yang positif, prestasi yang dimiliki, dan juga kesejahteraan psikologis (Baumeister \& Vohs, 2016).

Dalam kehidupan, self-esteem sendiri terbentuk karena faktor lingkungan dan interaksi yang dilakukan oleh individu, sehingga 
jika interaksi yang dilakukan memberikan kesan yang menyenangkan maka self-esteem menjadi positif, sebaliknya jika interaksi dalam lingkungan tersebut memberi kesan yang tidak menyenangkan maka self-esteem menjadi negatif. Hal ini dapat memunculkan low selfesteem atau self-esteem yang rendah, seperti banyak fenomena negatif yang salah satunya terhadap media sosial yang dikonsumsinya secara audio visual akan terjadi imitasi perilaku, jika seseorang kurang pengetahuan maka ia akan melakukan komparasi terus menerus yang menjadi nilai ukur sendiri sehingga ia akan mengalami stress hingga membentuk low selfesteem, pada ranah kognitif apabila seseorang menerima informasi dan juga mengelola serta mengintepretasikannya akan mengalami proses pemilahan, hal ini disampaikan oleh Wood bahwa schemata atau yang dikenal sebagai cognitive schemata ini informasi akan diatur, yang mana dalam pengaturannya ini dipengaruhi oleh prototype, personal construct, stereotype, dan script (Wood, 2014).

Self-esteem yang kuat juga menjadi salah satu faktor keberhasilan yang diperoleh individu dalam kehidupannya. Dimana hal ini sebagai penilaian terhadao dirinya sendiri, maka menjadi bagian penting dalam pendidikan salah satunya yakni pengembangan self-esteem, sehingga diharapkan mereka mampu memproses penemuan konsep diri yang dinilai positif bagi jiwa anak. Demikian juga seperti yang disampaikan oleh Nathaniel Branden mengenai self-esteem yang merupakan,

1. Keyakinan yang dimiliki individu dalam bertindak dan menghadapi tantangan baru dalam kehidupan.

2. Keyakinan yang kita miliki sebagaimana hak kita dalam merasakan bahagia, perasaan untuk dihargai dan berharga, rasa layak, memungkinkan untuk menegaskan keinginan dan kebutuhan yang mana juga untuk menikmati buah dari hasil upaya kerja keras yang sudah kita lakukan (Branden, 1992 ; Refnadi, 2018).

Proses perkembangan dalam self-esteem dimulai melalui hubungan interpersonal dari bagian terinti yakni keluarga yang seiring berjalannya waktu secara bertahap terpengaruh melalui lingkungan sekolah dan pengaruh dari lingkungan sekitar yakni lingkup masyarakat lebih luas, serta dalam umur yang lebih dewasa individu tinggal dan bekerja dimana pada akhirnya potensi yang mereka miliki menjadi penentu nasib mereka (Nikmarijal \& Ifdil, 2014).

\section{Interaksionisme Simbolik}

Teori Interaksionisme Simbolik berusaha memahami fenomena sosial ini dengan mengkaji bagaimana cara individu melihat suatu simbol. Tindakan repetisi ini keberadaan makna yang sebenarnya telah berubah di benak pelakunya terhadap suatu simbol. Blumer mengatakan bahwa istilah interaksionisme simbolik merujuk pada sifat yang terjadi antar interaksi manusia. Manusia saling menafsirkan 
dan mendefinisikan perilaku satu sama lain. Bukan sekedar tanggapan atas tindakan orang lain, tetapi berdasarkan "makna" yang diberikan atas tindakan orang lain.

Interaksi antara individu dimediasi melalui penggunaan simbol, interpretasi, atau melalui upaya bersama untuk memahami niat tindakan masing-masing. Dalam teori ini dijelaskan bahwa perilaku manusia bukan disebabkan oleh "kekuatan - kekuatan eksternal" (dalam pengertian fungsionalis struktural), juga bukan disebabkan oleh "kekuatan - kekuatan internal" (dalam pengertian reduksionisme psikologis), tetapi berdasarkan pada hal-hal mereka hadapi Makna melewati proses ini, yang disebut Bloomer sebagai sugesti diri (Ahmadi, 2008).

Blumer lebih lanjut menunjukkan bahwa interaksi manusia dijembatani oleh penggunaan simbol, interpretasi, dan determinisme makna tindakan orang lain, bukan hanya berinteraksi seperti dalam model stimulus-respon. Interaksionisme simbolik cenderung mengidentifikasikan diri dengan proses kausal interaksi sosial. Dalam arti, makna tidak tumbuh dengan sendirinya, tetapi muncul dari proses dan kesadaran manusia.

\section{Literasi Digital}

Literasi digital ialah keterampilan dalam menggunakan media secara efektif sehingga individu dapat mengetahui sumber referensi yang relevan dan valid (Limilia \& Aristi, 2019). Dalam materi pendukung literasi digital menurut Paul Gilster dalam Aziz dkk. (2020), diartikan sebagai kemampuan untuk memahami dan menggunakan informasi dalam berbagai bentuk dari berbagai sumber yang sangat luas yang diakses melalui perangkat komputer. Kemudian ia juga memperluas konsep dari literasi digital yakni sebagai kemampuan memahami dan menggunakan sumber informasi yang didapat dari berbagai media digital sebagai kepentingan pengembangan diri maupun individu. Hal ini merujuk pada kemampuan membaca, menulis, dan juga berkitan dengan informasi yang akan menentukan seorang individu serta organisasinya berkembang. Konsep literasi digital sendiri dimulai dari proses yang cukup panjang, dimana konsep ini terus melakukan transformasi dari masa ke masa (Budiarti dkk., 2021 ; Potter, 2010).

Marshall McLuhan dalam Ratana (2018), menyatakan bahwa kemunculan dengan memperoleh informasi yang instan seperti saat ini berawal dari tersedianya internet. Revolusi ini berubah terjadi karena adanya perubahan dalam media informasi yang biasanya didapatkan bukan dengan sendirinya tetapi dalam bentuk siaran. Ketika melakukan interaksi yang terjadi dalam media komunikasi, keterikatan pada media juga dipengaruhi oleh efisiensi dan kontrol oleh pengguna atas media yang digunakannya.

Hal ini seperti yang dikemukakan oleh Turkle dalam Saleh dan Pitriani (2018), yang mengeksplorasi mengenai bagaimana pengguna menggunakan perangkatnya yang seakan-akan 
memiliki pikiran dan jiwa yang kemudian menggantikan proses interaksi tersebut dari manusia secara langsung, karena dalam komunikasi digital pengguna memiliki identitas secara online sehingga pengguna dapat mengendalikan seberapa banyak ia mengungkapkan identitasnya, dan dengan mudah dan nyaman berekspresi di dunia maya dibandingkan dengan dunia nyata.

\section{METODE KEGIATAN}

Dari rumusan masalah yang telah diuraikan sebelumnya, maka metode kegiatan PkM ini menggunakan konsep diskusi interaktif. Terdapat tiga tahapan yakni:

\section{Tahap Persiapan}

Pada tahap persiapan yang merupakan tahap awal sebelum dilakukannya pelaksanaan kegiatan. Sehingga dimana dalam tahapan ini dilakukan penyebaran kuesioner dengan mitra terkait yakni Sekolah Teman Belajar di Cipinang Besar Utara, Jakarta Timur. Setelah menyebarkan kuesioner, para fasilitator merancang pelatihan pengembangan dan inovasi kepada tim. Selain itu, para fasilitator juga melakukan pertemuan dengan pihak terkait yakni yayasan mitra Sekolah Teman Belajar untuk melakukan brainstorming terkait ide atau konsep pada saat pelatihan yang akan diberikan kepada peserta didik yang mana mereka ini adalah anak-anak yang masih duduk di bangku Sekolah Dasar (SD). Selanjutnya, adanya situasi pandemi ini maka hasil pertemuan akan dilakukan diskusi secara online melalui aplikasi
Zoom terkait pembagian tugas sesuai dengan perannya saat pelaksanaan kegiatan pengabdian tersebut.

Saat pertemuan internal melalui pertemuan online, mahasiswa akan di brief terlebih dahulu mengenai medannya yakni karakteristik peserta didik, orang tua peserta didik yang juga akan dilibatkan dalam pelatihan dan pendampingan nantinya. Pertemuan akan dilakukan secara berkala, dengan agenda yang sudah dibuatkan dalam timeline. Fasilitator bersama mahasiswa Universitas Bakrie dalam pelaksanaan pengabdian nanti peserta akan diberikan pengetahuan dan wawasan melalui pembinaan pengemasan konten dengan mengaitkan wawasan budaya Indonesia yakni mengangkat nilai-nilai budaya kesantunan sederhana yang dapat diterapkan dalam kehidupan sehari-hari.

\section{Tahap Pelaksanaan}

Tahap pelaksanaan, dalam tahapan ini fasilitator melakukan pelatihan dan pendampingan mengenai pemahaman literasi digital mengenai faktor apa saja yang akan memengaruhi dan efek yang dihasilkan untuk kedepannya. Diharapkan saat kegiatan pengabdian ini orang tua peserta turut partisipasi dalam pelatihan dan pendampingan. Metode yang akan dilakukan adalah pendekatan secara langsung dan online dimana pelatihan dan pendampingan, mahasiswa yang tergabung dalam tim PkM akan hadir di lokasi. Pelaksanaan akan dilakukan sesuai dengan protokol kesehatan yang berlaku. 
Pendampingan akan menggunakan aplikasi Cisco Webex Meeting. Pada tahapan ini juga fasilitator melakukan brainstorming session kembali dengan para panitia agar membuat webinar yang interaktif kepada pesertanya. Selanjutnya, peserta dalam kegiatan ini adalah remaja generasi $Z$ dengan rentan usia 9 sampai 12 tahun maka pada tahapan ini power point yang dibuat harus menarik dengan menggunakan animasi slide, text dan gambar yang bervariasi. Selain itu, presentasi nantinya akan dipadukan dengan menyisipkan kuis yang bersifat interaktif.

Selain itu, pelaksanaan nanti peserta juga dibekali materi terkait dasar-dasar membuat ide dan menulis konten, fotografi, serta videografi. Hal ini bertujuan agar peserta memahami bukan hanya sekedar memiliki akun media sosial akan tetapi bagaimana dapat mengoptimalkan pemanfaatan media sosial tersebut dengan tujuan yang jelas, seperti mengenalkan aspek budaya yang dapat meningkatkan self-esteem content creator-nya.

Pada tahapan ini, orang tua peserta dilibatkan mulai dari kegiatan pembekalan dari awal, hal ini dimaksudkan agar orang tua pun juga mendapatkan pemahaman dan pengetahuan mengenai penggunaan media sosial, yang mana ketika anak-anak mereka menggunakan media sosial tidak diabaikan namun didampingi karena peran mereka sangat penting.

\section{Tahap Evaluasi}

Pada tahapan evaluasi kegiatan dilakukan evaluasi berupa questionnaire menggunakan Google Form berupa Online Quiz dan Online Polling untuk mendapatkan gambaran umpan balik peserta dari pelaksanaan edukasi berdasarkan kegiatan yang telah dilakukan secara berkala, baik sebelum pelaksanaan pemberian materi, sebelum mengunggah video konten edukasi hingga setelah pelaksanaan pemberian materi dan setelah peserta menonton video konten edukasi pada kanal media sosial. Masukan dan perbaikan lebih lanjut dapat dilakukan pada tahap ini, sehingga untuk mendapatkan e-certificate peserta diminta memberikan feedback terkait pelaksanaan kegiatan yang sudah dilakukan.

Hasil monitoring dan evaluasi pelaksanaan kegiatan akan menggunakan perhitungan statistik untuk mendapatkan hasil kuantifikasi dari masing-masing score online survey, interactive quiz dan online polling. Adapun datadata hasil perhitungan statistik tersebut akan digunakan sebagai data awal pengembangan aplikasi terkait media sosial yang lebih aman bagi anak-anak. Kemudian, indikator keberhasilan program pengabdian kepada masyarakat ini adalah persentase peningkatan hasil score jawaban questionnaire, quiz, online survey yang ditanyakan kepada peserta program pengabdian. Hasil score tersebut akan dibandingkan antara score sebelum kegiatan dan score sesudah kegiatan pengabdian, dimana 
pertanyaan-pertanyaan yang diajukan menitikberatkan pada kedalaman pemahanan peserta mengenai wawasan kebangsaan nasional. Berikut terlampir bagan dari penjelasan metode kegiatan PkM:

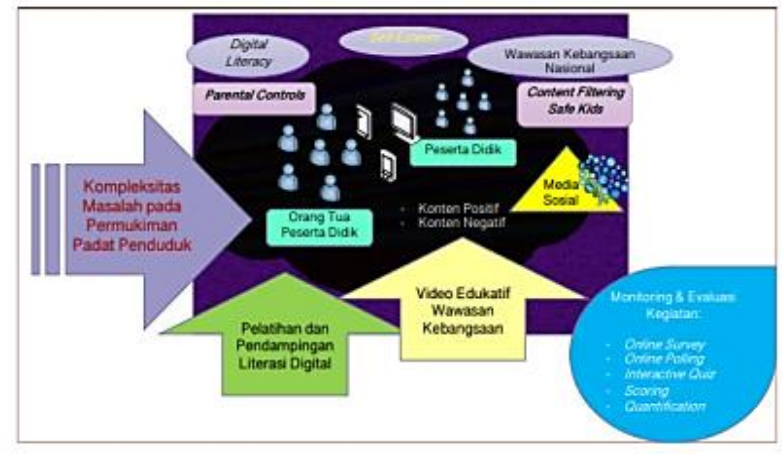

Gambar 1. Skema Metode Pelaksaaan Kegiatan

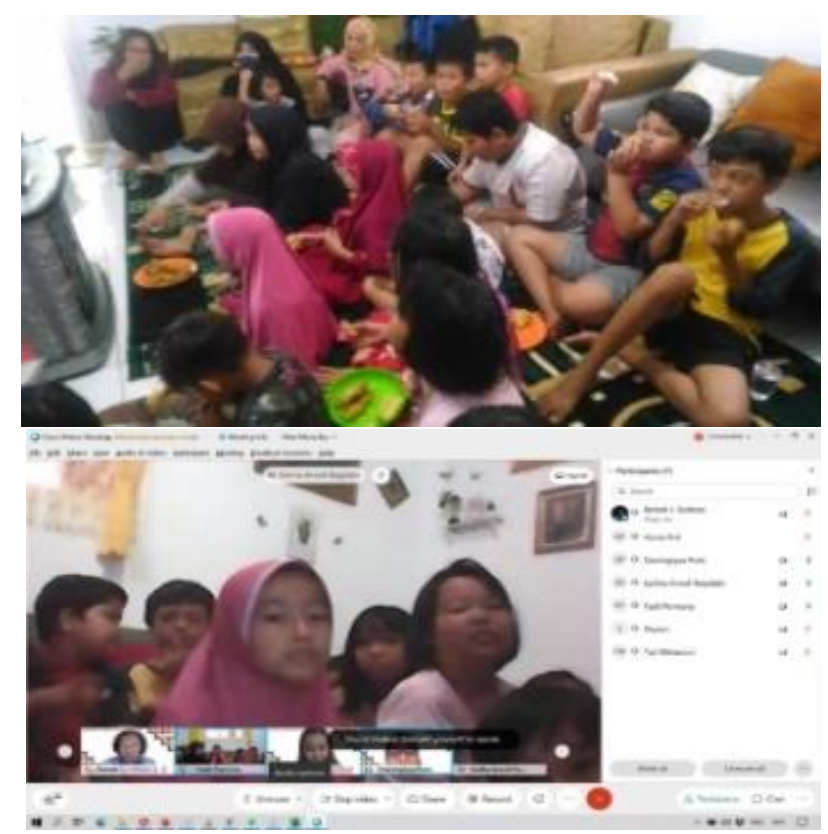

Gambar 2. Kegiatan Pengabdian melalui Webex

Adapun kriteria kegiatan dalam pengabdian ini adalah :

1. Pemateri menguasai mengenai wawasan kebangsaan nasional, literasi digital, serta self-esteem.

2. Jenis kegiatan pengabdian ini adalah diskusi interaktif dengan konsep interactive experience sharing.
3. Terdapat sesi diskusi dan sharing, dimana pada kesempatan ini fasilitator dan mahasiswa turut dilibatkan dalam memperkenalkan keluarga Arjuna dan Srikandi versi animasi kepada peserta didik, yang nantinya tokoh Arjuna dan Srikandi sebagai ikon Sobat Mainku.

4. Fasilitator dan mahasiswa mengajak partisipan untuk menuangkan ide cerita. Lalu, dari ide cerita tersebut akan dituangkan ke dalam animasi Arjuna dan Srikandi.

5. Menggunakan tokoh pewayangan sebagai kearifan lokal budaya asli Indonesia, melalui video animasi. Hal ini merupakan inovasi baru dan kreatif dengan memadukan teknologi digital, yang mana pagelaran wayang biasanya diselenggarakan secara tradisinonal namun kali ini dikemas secara animasi.

6. Partisipan dalam kegiatan ini adalah generasi Z dengan rentan usia 9 sampai 12 tahun.

\section{HASIL DAN PEMBAHASAN}

Usai dijelaskan dari uraian di atas, terkait dengan topik yakni literasi digital dalam pembentukan self-esteem dengan berwawasan kebangsaan nasional di Sekolah Teman Belajar Cipinang Jakarta Timur dilakukan melalui tiga tahapan sebagai berikut:

\section{Tahap Persiapan}

Adanya situasi pandemi saat ini, kegiatan dilakukan secara online baik saat pertemuan dengan tim dan pelaksanaan kegiatan 
pendampingan dan pembekalan yang diberikan kepada mitra. Pada tahapan ini, tim melakukan penyebaran kuesioner pada mitra terkait, yakni Sekolah Teman Belajar di Cipinang Besar Utara, Jakarta Timur.

Tujuan dilakukannya penyebaran kuesioner, agar tim dibantu dengan mitra untuk mengetahui apa yang dibutuhkan serta topik pembahasan yang cocok untuk mitra. Kemudian, hasil dari kuesioner tersebut di diskusikan dengan pihak mitra untuk merancang pelaksanaan kegiatan pengabdian terkait pendampingan dan pelatihan literasi digital nantinya, serta dilakukan brainstorming terkait ide atau konsep pada saat pelatihan yang akan diberikan kepada peserta didik yang masih duduk di bangku Sekolah Dasar (SD).

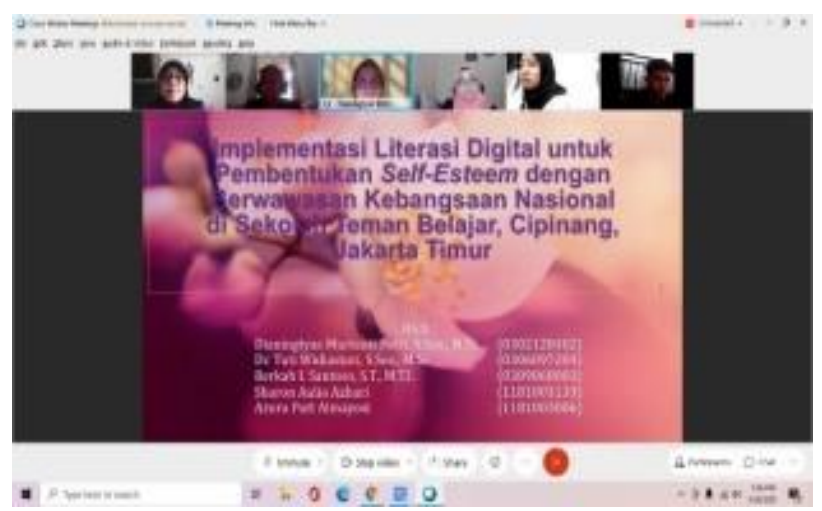

Gambar 3. Pertemuan Pra-Pengabdian dengan Tim

Selain pertemuan dengan pihak mitra, juga dilakukan pertemuan internal untuk menyamakan persepsi. Dalam pertemuan ini, pembahasan yang disampaikan terkait brief mengenai karakteristik peserta didik, orang tua peserta didik yang juga akan terlibat dalam pelatihan dan pendampingan nanti, serta mahasiswa yang tergabung dalam tim PkM juga dilibatkan untuk memberikan insight dalam membuat video animasi Arjuna dan Srikandi.

Pertemuan tim ini dilakukan secara berkala sesuai dengan timeline yang sudah dibuat, serta tim diberikan pemahaman mengapa konsep pengemasan konten melalui media sosial dengan mengangkat nilai-nilai budaya Indonesia sebagai metode literasi digital ini penting sebagai pembekalan dan pendampingan yang harus diberikan kepada peserta didik mitra.

Selain membahas peran tanggung jawab mahasiswa dilibatkan dalam kegiatan pengabdian ini, mereka juga diminta untuk memberikan tanggapan mengenai konsep pembekalan yang diberikan pada peserta, sebab fasilitator bersama mahasiswa Universitas Bakrie dalam pelaksanaan pengabdian, peserta akan diberikan pengetahuan dan wawasan melalui pembinaan pengemasan konten dengan mengaitkan wawasan budaya Indonesia yakni mengangkat nilai-nilai budaya bangsa.

\section{Tahap Pelaksanaan}

Kegiatan yang dilaksanakan selama 2,5 jam melalui Cisco Webex Meeting yang dihadiri oleh remaja dengan rentan usia 9 sampai 12 tahun. Pada pelaksanaan pelatihan dan pendampingan ini, pemateri menciptakan iklim komunikasi yang kondusif. Pendekatan fasilitator pada peserta ialah melakukan komunikasi visual dengan menyiapkan video edukatif selain menggunakan power point yang kreatif sebagai pembuka kegiatan yang dapat memberikan 
gambaran secara deskriptif mengenai intensitas yang tinggi dalam penggunaan media sosial.

Selain itu, fasilitator dan tim PkM juga menyiapkan gift berupa voucher GoPay atau OVO bagi para pemenang kuis. Metode yang akan dilakukan adalah pendekatan secara langsung dan online dimana pelatihan dan pendampingan mahasiswa akan hadir di lokasi.

Pada tahapan ini pelaksanaan pembekalan yang diberikan pada peserta berlangsung cukup baik, karena ada kendala yang ditemukan, yakni minimnya ketersediaan fasilitas yang dimiliki oleh mitra, yang hanya menggunakan laptop saja dan tidak didukung dengan perangkat lainnya, sehingga noise tidak terhindarkan. Kendala lainnya adalah adanya hambatan dalam ketersediaan sinyal membuat terhambatnya pelaksanaan pelatihan online ini, akan tetapi hal ini masih dapat teratasi dengan tetap melakukan pendampingan.

Meskipun adanya kendala yang dihadapi di lapangan ketika acara berlangsung, disini fasilitator menciptakan iklim komunikasi yang interaktif dan kondusif. Lalu, pengemasan pesan yang diberikan pada peserta diberikan dengan gaya bahasa yang sederhana serta menggunakan power point dan video sebagai tools agar memudahkan peserta dapat memahami materi yang disampaikan.

Dalam tahap pelaksanaan ini, dibagi dalam dua sesi kegiatan yakni, kegiatan pertama fasilitator memberikan penjelasan mengenai fenomena sosial, karakteristik media sosial, serta apa yang boleh dan tidak boleh dilakukan dalam penggunaan internet. Dilanjutkan dalam sesi kedua, mengenalkan dua tokoh pewayangan yakni Arjuna dan Srikandi.

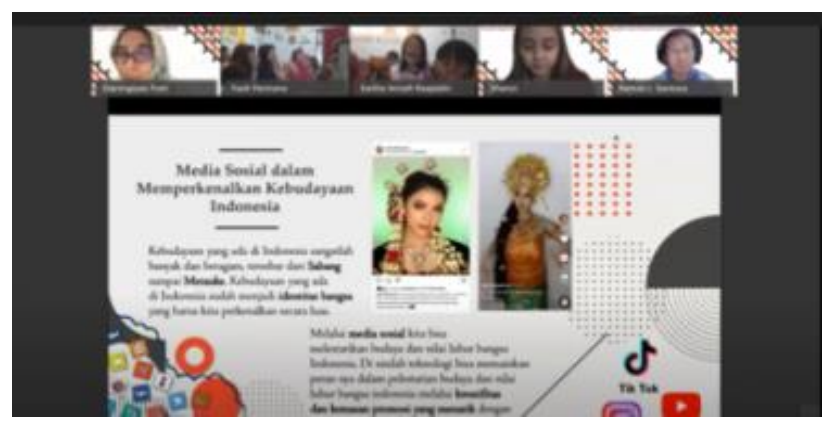

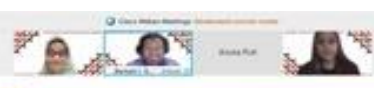

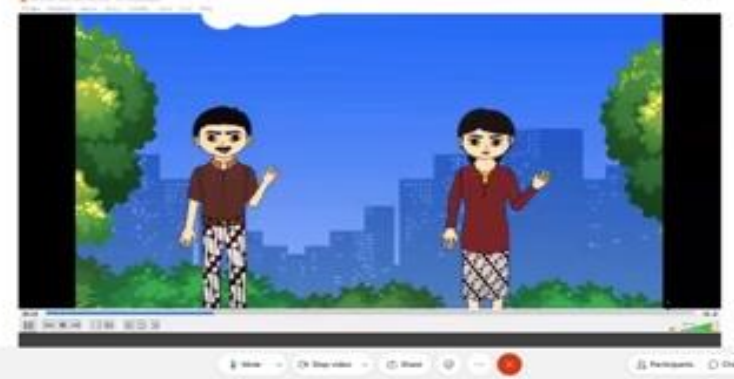

Gambar 4. Fasilitator Menyampaikan Materi dan Memperkenalkan Karakter Arjuna dan Srikandi

Selain itu, dalam tahap pelaksanaan juga peserta distimulus untuk membuat ide cerita, yang hasilnya nanti akan dituangkan dalam animasi Arjuna dan Srikandi kemudian ditampilkan di media sosial sobatmainku. Dimana bertujuan sebagai proses pembentukan self-esteem dalam diri. Dengan kata lain, kegiatan ini merupakan suatu apresiasi karya yang diberikan dari mitra dan untuk mitra.

\section{Tahap Evaluasi}

Selama pelaksanaan respon dari anak-anak cukup interaktif. Disini, anak-anak perlu dorongan yang bertujuan untuk memancing mereka dalam bertindak dan menyampaikan pendapatnya. Dengan maksud, menumbuhkan 
keberanian dan inisiatif dari peserta. Selain itu, fasilitator mengingatkan pada peserta untuk jangan malu untuk mengajak orang tua mereka saat menggunakan media sosial.

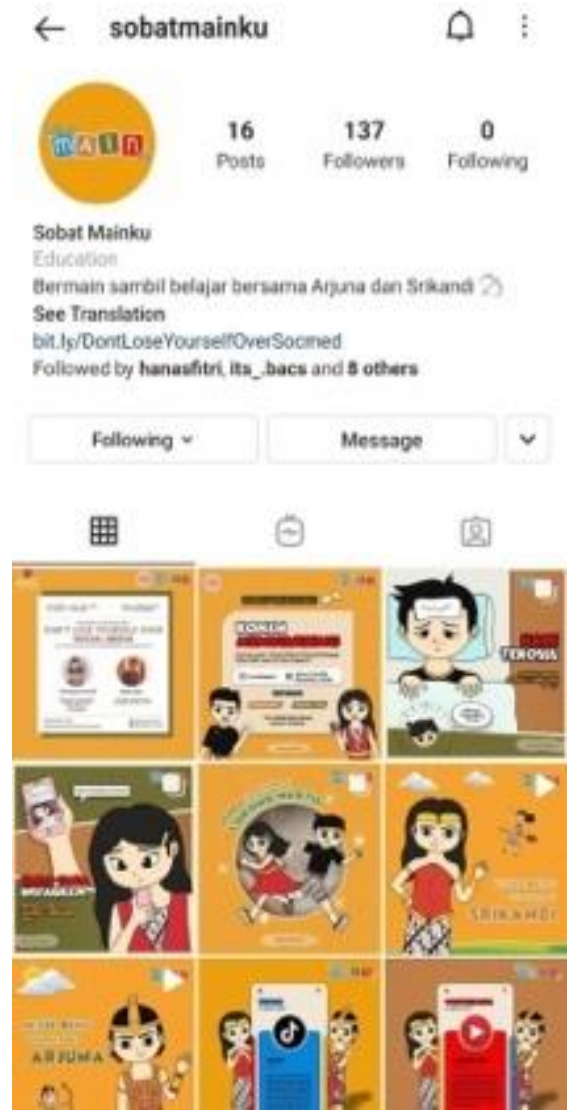

Gambar 5. Memperkenalkan melalui Media Sosial Instagram

Mengingat banyaknya konten yang dikemas melalui media sosial, namun kurang mengangkat terkait wawasan kebangsaan nasional sebagai identitas bangsa maka fasilitator menyampaikan juga pada para orang tua bahwa penggunaan media sosial mencerminkan bukan hanya identitas diri namun, merepresentasikan identitas bangsa. Disini, untuk menjembatani yang dimaksudkan ke peserta didiknya yaitu anak-anak maka dikenalkan dua tokoh pewayangan yang diharapkan peserta dapat belajar mengenal budaya bangsa melalui tokoh Arjuna dan Srikandi.

Selama pengenalan tokoh tersebut melalui video animasi, sangat membantu peserta untuk mengenal tokoh pewayangan. Terlihat antusiasme peserta dalam memberikan tanggapan dengan menceritakan kembali dari penyajian video animasi yang diberikan. Sebagian besar peserta mengenal media sosial, akan tetapi belum mengetahui penggunaannya ditujukan untuk apa.

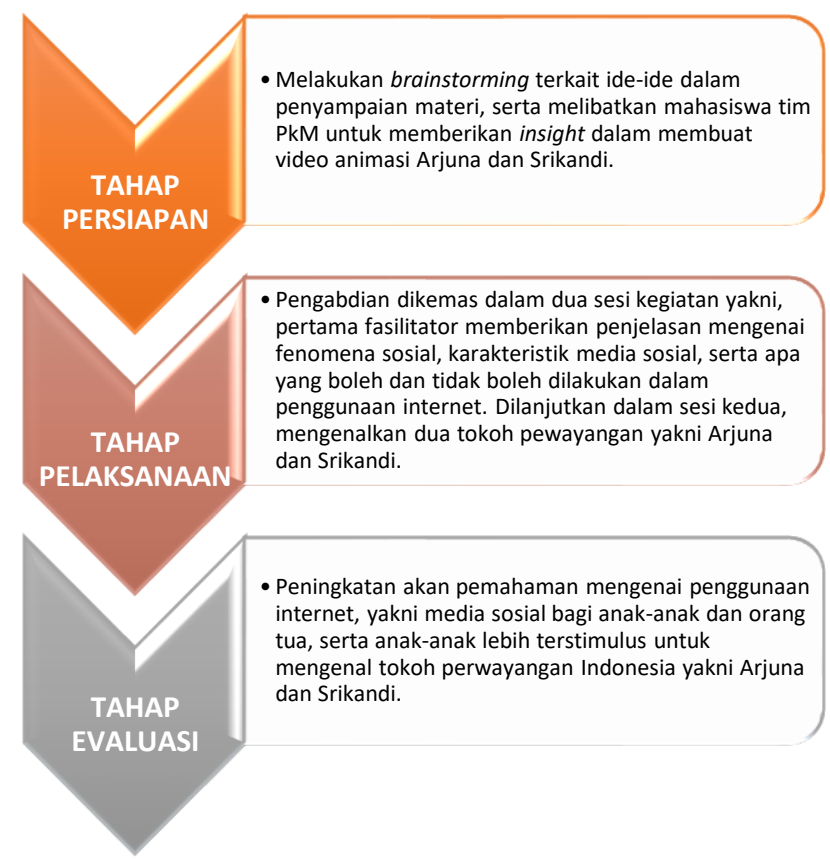

Gambar 6. Alur Kegiatan Pengabdian Literasi Digital dalam Pembentukan Self-Esteem dengan

Berwawasan Kebangsaan Nasional di Sekolah Teman Belajar Cipinang Jakarta Timur

Media sosial yang sangat digemari oleh peserta adalah media sosial Instagram dan TikTok. TikTok digunakan sebagai media hiburan joget, sedangkan Instagram untuk foto-foto, dapat diambilkan kesimpulan bahwa peserta mengetahui kegunaan secara umum, namun tujuan dan bahayanya dari penggunaan media sosial secara intens dan tidak didampingi inilah 
yang akan memengaruhi kesehatan mental mereka. Oleh sebab itu, peran psikologi komunikasi yang termasuk dalam ilmu komunikasi ini sangat penting diberikan melalui kegiatan literasi digital.

\section{KESIMPULAN}

Berdasarkan dari hasil kegiatan pengabdian di Sekolah Teman Belajar di Cipinang, Jakarta Timur. Peserta yang mengikuti dapat memahami karakteristik media sosial sesuai dengan penggunaannya, kemudian mengetahui gambaran bahayanya penggunaan media sosial yang sangat intens tanpa didampingi oleh keluarga. Selain itu, orang tua peserta didik pun juga memahami benefit dan dampak dari media sosial bagi anak-anak mereka.

Pemilihan kalimat yang digunakan saat memberikan materi dan diskusi dalam kegiatan ini dipilih menggunakan kalimat yang mudah dipahami, juga tools untuk menjembatani materi yang diberikan. Adanya pandemi, sehingga kegiatan pengabdian hanya dapat dilakukan secara online dan salah satu anggota tim Pengabdian kepada Masyarakat (PkM) yang hadir dalam kegiatan.

Kecenderungan anak-anak yang lebih menyukai visual, menambah kesan ketertarikan anak-anak, sehingga selain menambah ilmu pengetahuan mereka, secara tidak langsung mereka juga terstimulus untuk lebih mengenal karakter-karakter perwayangan Indonesia salah satunya yakni Arjuna dan Srikandi.
Pada perubahan dalam sasaran kondisi kegiatan, dimana sebelumnya audiens tidak memahami terkait karaktersitik dan jenis jenis media sosial, serta dengan penggunaan internet yang nyatanya dibutuhkan pendampingan oleh orang tua, sehingga dengan kegiatan pengabdian ini fasilitator beserta tim melakukan pelatihan dan pendampingan bukan hanya kepada anak-anak saja tetapi juga kepada orang tua mereka, dengan memberikan pemahaman terkait parenting education. Sehingga, orang tua dapat mendampingi anak-anaknya dalam penggunaan internet, terlebih untuk anak-anak usia dini. Kemudian, fasilitator dan tim juga berperan dalam memberikan wawasan kebangsaan kepada anak-anak yang sebelumnya anak-anak belum mengenal tokoh-tokoh perwayangan Indonesia, namun dengan adanya kegiatan ini mereka belajar mengenal tokoh perwayangan Indonesia melalui Arjuna dan Srikandi.

\section{UCAPAN TERIMA KASIH}

Terima kasih kepada Lembaga Pengabdian kepada Masyarakat Universitas Bakrie yang telah memfasilitasi dalam pelaksanaan kegiatan PkM ini. Kemudian para peserta didik dan orang tua di Sekolah Teman Belajar, Cipinang Jakarta Timur yang turut serta dan terlibat dalam kegiatan ini. 


\section{DAFTAR PUSTAKA}

Ahmadi, Dadi (2008). Interaksi Simbolik. Jurnal Mediator, 9(2), 301-316.

Aziz, R. M., Syam'aeni, M. A., Sya'baniyah, N., \& Fatihah, I. C. (2020). Peningkatan Kemampuan Literasi Digital bagi Siswa Kelas 4 dan 5 SDN Tanjakan 3, Kabupaten Tangerang. Jurnal Pengabdian Pada Masyarakat, 5(1), 141-148.

Baumeister, R. F., \& Vohs, K. D. (2016). Handbook of Self-Regulation:Research, Theory and Aplication 3rd Edition. New York: The Guilford Press.

Belshaw, D. (2011). What is Digital Literacy? A Pragmatic Investigation [Tesis]. University of Durham, Durham.

Budiarti, A., Arini, D., Hastuti, P., Ernawati, D., Saidah, Q., Fatimati, I., Faridah, \& Dewinta. (2021). Edukasi Kesehatan Pencegahan Covid-19 Dalam Perubahan Pengetahuan Masyarakat Kalipecabean Sidoarjo. Jurnal Pengabdian Kepada Masyarakat, 1(2), 213218.

Jenkis, R. (2018). Generation Z vs. Millennials:

The 8 Differences You Need to Know. Diakses dari https://hrdailyadvisor.blr.com/ 2017/09/25/generation-z-vs-millennials-8-d ifferences-need-know/

Limilia, P., \& Aristi, N. (2019). Literasi Media dan Digital di Indonesia: Sebuah Tinjauan Sistematis. Jurnal Komunikatif, 8(2), 205220.
Nikmarijal, \& Ifdil. (2014). Urgensi Peranan Keluarga bagi Perkembangan Self-Esteem Remaja. Jurnal Konseling dan Pendidikan, 2(2), 19-24.

Potter, W. J. (2010). The State Of Media Literacy. Journal of Broadcasting and Electronic Media, 54(4), 675-696.

Putri, D., \& Listriani, D. (2021). Perkembangan Peserta Didik Sebuah Tinjauan Teori dan Praktis (Mendorong Kemandirian Gen Z Melalui Komunikasi Antar Pribadi Untuk Meningkatkan Self-Efficacy saat Pandemi Covid-19). Bandung: Widina Bhakti Persada. Rakhmat, J. (2018). Psikologi Komunikasi. Bandung: Simbiosa Rakatama Media.

Ratana, M. (2018). Pengaruh Social Media Marketing terhadap Ekuitas Merek (Program Crowdscourcing Foto Periode 18 Juli 2016 - 2 April 2017 di Instagram). Jurnal Studi Komunikasi dan Media, 22(1), $13-28$.

Refnadi, R. (2018). Konsep Self-Esteem serta Implikasinya Pada Siswa. Jurnal EDUCATIO: Jurnal Pendidikan Indonesia, 4(1), 16-22.

Saleh, G., \& Pitriani, R. (2018). Pengaruh Media Sosial Instagram dan WhatsAp terhadap Pembentukan Budaya "Alone Together". Jurnal Komunikasi, 10(2), 103-114.

Samovar, L., Porter, R., \& McDaniel, E. (2013). Komunikasi Lintas Budaya. Jakarta: Salemba Humanika. 
Badan Pusat Statistik. (2017). Kajian Aktual Tulgan, B., \& Rainmaker. (2013). Meet Penguatan Wawasan Kebangsaan dan Generation Z: The Second Generation Ketahanan Nasional Pada Generasi Muda within The Giant "Millennial" Cohort. Terhadap Pengaruh Budaya Asing, 2017. Diakses dari http://rainmakerthinking.com/ Distem Informasi Rujukan Statistik. Diakses assets/uploads/2013/10/Gen-Z-Whitepape dari https://sirusa.bps.go.id/sirusa/index.ph r.pdf

p/sektoral/view?kd=14079\&th=2017

Wood, J. T. (2014). Communication Mosaics: An Introduction to the Field of Communication Seventh Edition. USA: Wadsworth. 